\title{
A note on the timing of dividend receipts in share returns
}

\author{
Paul van Rensburg*, Kevin Slaney \& Phillipe Hardy \\ Department of Accounting and Finance, University of Nata, King George V Avenue, Durban, 4001 Republic of South Africa
}

Received October 1997

\begin{abstract}
Researchers in financial economics conventionally include dividend receipts as returns received on their date of payment. This article argues that this procedure misrepresents the economic timing of shareholder returns. A theoretical discussion of the ex-dividend effect and an empirical investigation of this phenomenon on the Johannesburg Stock Exchange are used to motivate the contention that researchers would be more correct to incorporate dividend receipts in share returns on their 'ex dividend' rather than payment dates. This argument has particular relevance for those financial researchers employing monthly share price data. A failure to make this adjustment generally results in four out of twelve observations of share returns being characterized by measurement errors (the payment date generally being in the month following the exdividend date).
\end{abstract}

*Author to whom all correspondence should be addressed.

\section{Introduction}

Cash dividend payment is a process which involves three institutionalized events: first the dividend (and its magnitude) is declared by the company. Some two or three weeks following the declaration date, the stock is said to go 'ex dividend'. Investors wishing to receive the dividend must be registered before this ex-dividend date, as set by the firm. Third, on the payment date which is typically in the following month, the company pays the amount of the dividend to those investors who were registered before the ex-dividend date.

The overwhelming majority of studies that include dividends in returns appear to do so in the period in which the dividend is paid to the shareholder.' This is based on the implicit premise that this is the period in which the investor receives the cash payment and, hence, is the period in which his wealth increases. This article argues that this widely adopted procedure misrepresents the timing of share returns to the investor.

The argument can concisely be summarized as follows: it is proposed that share prices drop on the ex-dividend date by approximately the value of the prospective dividend. This proposition is justified on a priori considerations (second section), prior empirical evidence (third section) and a brief empirical investigation on the Johannesburg Stock Exchange (fourth section). This 'drop', however, does not represent a true change in shareholder wealth as those shareholders who experience this drop will be compensated in the form of an entitlement to a, yet to be received, dividend. In contrast, investors who purchase the share after the ex-dividend drop will not receive this entitlement when purchasing the (commensurately cheaper) share. Given that share prices reflect investor expectations regarding future dividend payments, it is argued that, in this context, the most precise way to think of dividend receipts is to view their entitlement as compensation for the ex-dividend drop in the share's resale value. Consequently, the tax adjusted present value of the dividend should properly be accrued to the shareholder on the ex-dividend date and no augmentation to capital gains should be made on the payment date. Appendix 1 graphically illustrates this argument.

\section{The ex-dividend effect}

The familiar dividend discount model postulates that the value of a share can be seen as the expected present value of all future dividend receipts from that share:

$$
P_{0}=\sum_{t=0}^{\infty} \frac{E_{0}\left(D_{t}\right)}{(1+k)}
$$

where:

$\mathrm{P}_{0} \quad=$ current price

$E_{0}\left(D_{)}\right)=$the dividend at time $t$ as expected at $t=0$

$\mathbf{k} \quad=$ the appropriate discount rate

Investors who purchase the share after the last day to register lose the right to one (in fact, the most proximate) of these future dividends. This right remains with the person registered as the shareholder on the ex-dividend date. It follows that the price should consequently fall by the present value of this dividend lost. Due to the short period of discounting (the payment date is up to two months after the last day to register) the present value of the dividend is likely to be only slightly less than the dividend's cash magnitude. This view of the (ceteris paribus) drop in the price is illustrated in panel 1 of Appendix 1. The notion that the price will drop on ex-dividend date is well established and goes back at least as far as 1924 (Durand \& May, 1960). .

The taxation payable on dividends has relevance for the changes in shareholder wealth as it results in a difference between the cash received by the investor and the assets lost by the company. The investor's valuation of the share will depend on his after tax cash receipt. Dividends have been taxed in a variety of ways in South Africa: (i) as a tax on the investor as part of his Normal Tax (1985-1989); (ii) as a tax on the company in the form of Secondary Tax on Companies (STC) (1992-1996); and during the period 1990-1992, dividends were not taxed.

In the case of Normal Tax, the investor receives the full dividend from the company. However, at the end of his tax year, he has to pay a percentage thereof over to the Receiver of Revenue. This percentage will depend on the investor's marginal tax rate and the section 19 dividend deduction (usually $33 \%$ of the dividend) if the investor is an individual, or the 
flat company tax rate at the time. Certain institutions, however, have been completely exempt from this tax.

It would be expected that the fall in the share price should be reduced by the tax that must be paid on the dividend:

$$
P_{\text {cum }}-P_{\text {ex }}=D\left(l-t_{D}\right)
$$

where:

$P_{e x}=$ the ex-dividend price of the share

$\mathrm{P}_{\mathrm{cum}}=$ the cum-dividend price of the share

$\mathrm{D}=$ the dividend

$t_{D}=$ the effective tax rate on dividends

However problems in making this taxation adjustment include the fact that each shareholder has a different marginal rate of $\operatorname{tax}\left(t_{D}\right)$ and thus a weighted average $t_{D}$ of all investors in each company would be needed to adjust dividends for tax. Also, the percentage of investors subject to capital gains tax on shares is normally not known. ${ }^{2}$ In the presence of capital gains tax as well as Normal Tax on dividends, the ratio $\left(\left(\mathrm{P}_{\text {cum }}{ }^{-}\right.\right.$ $\left.\left.\mathrm{P}_{\mathrm{ex}}\right) / \mathrm{D}\right)$ should equal the ratio of the Normal Tax rate applicable to dividends, to the tax rate applicable to capital gains from share appreciation (Elton \& Gruber, 1970).

Where the company is taxed in the form of STC, it will declare a set amount as a dividend and pay this full amount to the investor. The investor is then not taxed on this dividend. The company, however, is required to pay a percentage of this amount to the Receiver as STC. Thus, the company loses more assets than the investor gains, the difference being received by the Receiver of Revenue. It is speculated that on the ex-dividend date the value of the company should fall by the amount of the dividend alone in this situation. Assuming informational efficiency, the price of the share should already have fallen by the present value of all future expected STC payments over the life of the company. Share prices of dividend paying shares, however, should change when the government announces a change in the STC rate. The above is speculation on the part of the authors as no empirical research has yet been performed into the effect of STC on share price movements.

\section{Prior research on the ex-dividend effect}

In what appears to be the seminal study, Campbell \& Beranek (1955) found that the price of shares on the NYSE during the period October 1949 to April 1950 dropped by between $83 \%$ and $92 \%$ of the amount of the dividend declared (on the exdividend date), in the presence of taxes.

'The average stock price drop-off on the ex-dividend date tends to be about 90 per cent of the amount of the dividend when the stock market is otherwise stable'

(Campbell \& Beranek, 1955: 425).

An ex-dividend drop lower than the magnitude of the dividend is consistent with both the present value and taxation considerations discussed in the third section. Campbell \& Beranek however point out that, given the tax rates in operation at the time, the drop-off should have been between $65 \%$ and $75 \%$ of the dividend. In their study, the price dropoff was measured from the closing price on the day prior to the ex-dividend date to the opening price on the ex-dividend day.

Durand \& May (1960) found the average drop-off in the price of American Telephone and Telegraph stocks, on the ex- dividend date, during the period 1948-1959, to be $96 \%$ of the dividend declared (the actual drop-off in each period lay in the range $90 \%-102 \%)$. They concluded

'As we see it, the AT\& T experience provides only meagre support for the proposition that stocks tend to drop off by less than the amount of the dividend. Over the period studied, AT\& $\mathrm{T}$ tended to drop off by approximately the amount of the dividend ...'

Durand \& May (1960) used the closing price (rather than the opening price) on the ex-dividend date to remove any bias caused by the NYSE rule that all opening orders on the exdividend day be reduced by the amount of the dividend.

Elton \& Gruber (1970) found the drop-off in the price of NYSE stocks on the ex-dividend date in the period April 1966 to March 1967, to be on average $77 \%$ to $78 \%$ of the dividend declared, concluding that the market was rational with respect to the tax effects on dividends. The probability that the drop-off was greater than or equal to the amount of the dividend was found to be a mere 0.015 .

\section{Data and method}

To the authors' knowledge there is no published prior research investigating the ex-dividend effect on the Johannesburg Stock Exchange. The brief empirical component of this article employs a variant of the event study methodology of Fama, Fisher, Jensen \& Roll (1969) to examine share price behaviour on ex-dividend dates. The sample consists of 30 randomly chosen stocks listed on the Johannesburg Stock Exchange, with dividends declared semi-annually during the 'no tax' (1990-1992) period.

In the case of each share, daily closing prices for the 60 trading days prior to the last date to register and the 14 trading days following were gathered from the INET database at the University of Natal, Durban. In 28 cases there were six dividend announcements in the sample period; for the two remaining stocks dividends were announced five times. This yielded 178 series (one for each dividend declaration) of 75 observations (representing daily prices around these declarations). In some cases information about the security's closing price was not available, for example, due to public holidays being in the sample. When the previous day's closing price was available it was used. For those series for which closing price information was not available on the exdividend day or the day prior were excluded from the sample. The final sample consisted of 155 time series of daily stock prices around ex-dividend dates.

Arithmetic returns were calculated for each day $t$ :

$$
R_{i t}=\frac{P_{i t}-P_{i t-1}}{P_{i t-1}}
$$

Where $R_{i t}$ is the return of stock $i$ in period $t$ and $P_{i t}$ the price of stock $\mathrm{i}$ in period $\mathrm{t}$. The 'non-market related', or 'abnormal' returns, for the pre-event measurement period (that is, $t=-60$ to $t=-1$ ) are isolated using the market model:

$$
R_{i t}=\alpha_{i}+\beta_{i} R_{m i}+\varepsilon_{i t}
$$

where:

$R_{i t}=$ return of security $i$ in period $t$ 
$\alpha_{i}=$ constant term

$\beta_{i}=$ market model 'beta' of security $i$

$R_{m t}=$ return on the JSE All-Share Index in period $t$

$\varepsilon_{i t}=$ the residual error for security $\mathrm{i}$ at time $\mathrm{t}$

The abnormal returns for the pre-event measurement period are simply the residuals of the above regressions $\left(\varepsilon_{\mathrm{it}}\right)$.

$$
A_{i t}=\varepsilon_{u}=R_{i t}-\alpha_{i}-\beta_{i} R_{m s}
$$

Where $A_{i t}$ represents security i's abnormal return in period $t$. To calculate the security's abnormal returns during the event and post-event periods, the estimated $\alpha_{i}$ and $\beta_{1}$ from the preevent measurement period are imputed in the above equation.

Thereafter, each security's cumulative abnormal returns (cars) is calculated for each period $t$.

$$
c a r_{i t}=\sum_{t=-60}^{t=14} A_{i t}
$$

Where $\mathrm{car}_{\mathrm{it}}$ is the cumulative abnormal return of security $i$ in period t. Finally, the cars are aggregated over the entire sample for each period $\mathrm{t}$ :

$$
C A R_{i t}=\frac{\sum_{i=1}^{155} c a r_{i t}}{155}
$$

where: $\mathrm{CAR}_{1}=$ the mean cumulative abnormal return in period $t$.

Thus, a (common) variant of the Fama, Fisher, Jensen \& Roll (1969) event study methodology was adopted. Using equation (5) the effect of 'market' movements around the time of the event is extracted. To measure each stock's overall reaction to the event cumulative abnormal returns are calculated in equation (6). Firm specific events are diversified away in (7), the only remaining commonality between the share's returns being the reaction to the 'event'. (The shift from chronological time to 'event time', of course, also aids in eliminating confounding influences.)

\section{Results and interpretation}

Figure 1 graphically displays the results of the event study.

A clear and definite drop in CARs appears, as expected. The drop on the ex-dividend day is more pronounced than any other fluctuations in Figure 1. But two further features also become apparent.

First, after slowly decreasing for some 40 days or so, the CARs increase sharply between approximately period $t=-20$ to $t=0$. Second, the CARs continue to drop further for two or three days following the ex-dividend date. Only on day $t=+4$ do the CARs start to recuver. But they still remain lower than the value on the ex-dividend day.

These findings are consistent with those of Durand \& May (1960) who analysed the behaviour of the AT\&T stock near the ex-dividend date and found that the average price above or below the ex-dividend closing showed 'a tendency to rise steadily during the last two or three weeks before ex-dividend'. Furthermore, a decline in price subsequent to the exdividend date was also found by Durand \& May.

Calculating the average time difference between the date of declaration of dividends and the last day to register for dividends $(t=0)$, it was found that dividends were declared on average 23 days, or approximately 17 trading days $(t=-17)$ prior to the ex-dividend day. Closely examining Figure 1 it appears that the increase in cumulative abnormal returns tends to start some 21 trading days prior to the ex-dividend date. This corresponds to a period of some four trading days before the declaration date. Assuming informational efficiency and the fact that certain declaration dates are more than 17 trading days prior to the ex-dividend date, it is quite plausible that CARs should start rising a few days prior to the mean declaration date. It can be reasonably inferred that the observed increase in CARs is a consequence of dividend announcements.

To examine the magnitude of the ex-dividend price drop the mean ratio of the drop in price on the ex-dividend day to the

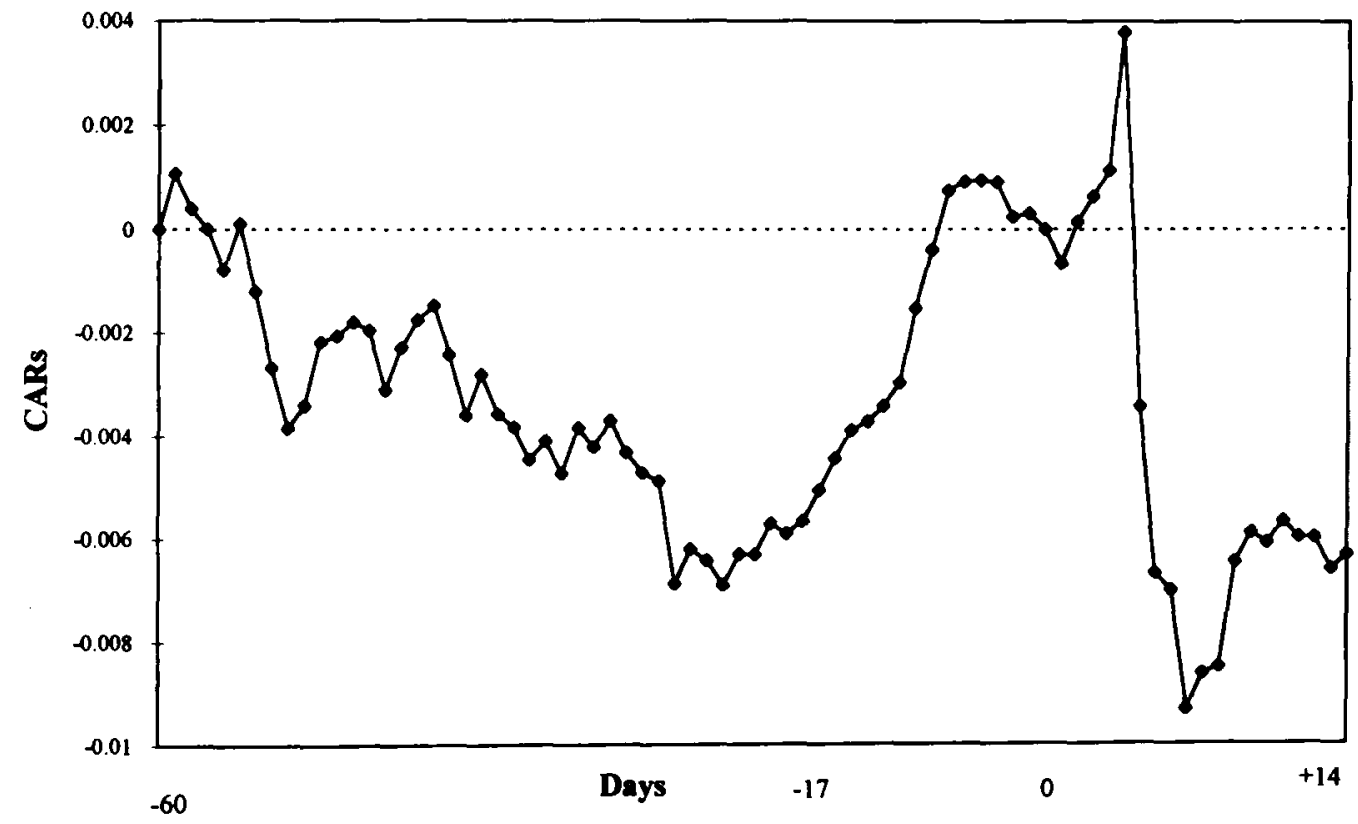

Figure 1 Mean cumulative abnormal returns around the ex-dividend date 
amount of the dividend was calculated. It was found that the average price drop-off for the entire sample was $59 \%$ of the dividend. However, this result should be interpreted with caution. Consistent with the findings of the CAR plot in a number of cases the price did not drop on the ex-dividend day itself but on a trading day closely following the ex-dividend date. (Note that although only trading days were examined in this study, this does not imply that each share actually traded on each day). There were 50 such cases in total and in the large majority of these the drop-off occurred within the four days immediately following. Focussing on just those instances where a stock price decrease did occur on the ex-dividend date itself, it was found that the mean magnitude of this drop was $116 \%$ of the dividend.

In broad terms, these findings suggest that the ex-dividend phenomenon does exist on the Johannesburg Stock Exchange and that, in the absence of a tax on dividends, the magnitude of the ex-dividend price drop is approximately the value of the dividend.

\section{Conclusion}

Consider a financial researcher employing monthly time series share return data. If the dividend component of share returns are ignored completely, the ex-dividend drop in the share price will result in a measurement error being present in those months in which the share goes ex-dividend. Similarly, if dividends are included in the month of payment, this period's return would represent an analagous ('upward') measurement error. As dividends are typically paid semiannually in South Africa and the ex-dividend date is typically in the month prior to the payment date, this implies that the inclusion of dividend receipts on their payment dates results in measurement errors in four of the twelve monthly observations of share returns. This constitutes a third of the sample.

To avoid this observational 'noise' on either date, dividends should be recognized on the ex-dividend date. (Of course, as the time period over which returns are measured increases, it becomes less likely that the ex-dividend and payment dates will occur in different periods, alleviating the necessity for this adjustment.) In this way, the measurement error that would otherwise exist on this date is partially corrected and none is created on the period of payment date. As discussed, the former correction is only partial to the extent that effect of the time value of the dividend between ex-dividend date and payment dates is ignored. In addition, no adjustment is made for the effect of the taxation on dividends.

Refinements to avoid these ambiguities should be based on the principle of excluding price movements which can be attributed to the ex-dividend effect, together with their corresponding dividend receipts, from the measurement of share returns. Of course, the practical difficulty with this procedure is that the researcher will now have to embark on the task of collecting and scrutinizing daily data, in the case of each dividend payment, to make appropriate adjustments to his sample.

\section{Notes}

1. Extracting a practicable sample from the infinitude of literature, volumes 16-21 of the South African Journal of Business Man- agement were surveyed. It was found that most studies either did not include dividend receipts in share returns or did not specify the date of inclusion. In the two cases where the dividend inclusion procedure was made explicit, dividends were included in their payment periods $(1988,19[4]: 143 ; 163)$. Research theses provide more detailed accounts of the dividend adjustment procedures adopted. Consider, one of the most experienced South African researchers:

'Consistent with prior research, security returns were computed using the natural logarithm of security prices after allowing for any market capitalisation issues. stock splits, and dividend receipts. Written mathematically;

$$
r_{t}=\ln \left(\frac{p_{t}+d_{t}}{p_{t-1}}\right)
$$

where; $r_{t}$ is the return or logarithm price relative from $t-1$ to $t ; p_{t}$ is the security price at time $\mathrm{t}$; and, $\mathrm{d}_{1}$ is the value of any dividend accruing between $1-I$ and $t^{\prime}$ [my emphasis] (Page, 1993: 3-16). In this case weekly and four-weekly data is used to investigate the distributional properties of security returns. The arguments in the text suggest that the conventional dividend adjustment procedure employed will result in the distributions estimated having spuriously thicker tails

The authors are not familiar with any study published to date employing the dividend adjustment procedure advocated in the text, nor of any paper making the reasons for doing so explicit. It is, thus, hoped that the simple arguments in this note will be of relevance to financial researchers in a wide variety of applica tions.

2. Only 'share dealers' are taxed on their capital gains, and then at their marginal tax rates. A 'share dealer' is deemed to be somebody who buys shares with the sole intention of receiving a capital gain and not the dividend.

\section{Acknowledgements}

Thanks to Prof Jean Miller for her proofreading and to Ms Elena Ilkova for preparing a presentable version of Figure 2. Thanks to an anonymous referee and Prof Linda Iluman for their constructive comments. All of the mistakes are ours.

\section{References}

Campbell J.A. \& Beranek. W. 1955. Stock price behanviour on ex-dividend dates, Joumal of Finance, 10: 425-429

Durand, D. \& May, A.M. 1960. The ex-dividend behaviour of American telephone and telegraph Stock, Journal of Finance, 15: 19-31.

Elton, E.J. \& Gruber, M.J. 1970, Marginal stockholder tax rates and the clientele effect, Review of Economics and Statistics, 52: 68-74.

Fama, E.F., Fisher, L., Jensen, M.C. \& Roll. R. 1969. The adjustment of stock prices to new information. Intemational Economic Review, 10: 1-21.

Hardy, P. 1995. The behaviour of stock returns on ex-dividend dates. Unpublished Research Report, University of Natal, Durban.

Page, M. J. 1993. The arbitrage pricing theory: an assessment of the robustness of empirical techniques employed under conditions of thin trading and in the presence of non-normalities. Unpublished $\mathrm{PhD}$ thesis, Cape Town: University of Cape Town.

Ross, S.A., Westerfield, R.W. \& Jaffe, J.F. 1993. Corporate Finance. 3rd Ed International Student Edition. Homewood. Illinois: Richard D. Irwin, Inc.

Slaney, K.B.E. 1996. An investigation into the share indices that proxy the macroeconomic forces underlying equity returns on the Johannesburg Stock Exchange. Unpublished MCom thesis. Durban: University of Natal.

Van Rensburg, P. 1997. Unifying the factor analyctic and prespecified variable approaches to APT factor identification on the JSE. Paper presented at SAFA Congress, Cape Town.

Van Rensburg. P. \& Slaney, K.B.E. 1997. Market segmentation on the Johannesburg Stock Exchange, Joumal of Studies in Economics and Econimetrics, 19(4): 1-25. 
Appendix 1 Timing of dividends receipts in share returns

(Adapted from Van Rensburg, 1997: 27.)

\section{THE TMMNG OF DIVIDEND RECEIPTS IN SHARE RETURNS}

1. The ex dividend effect

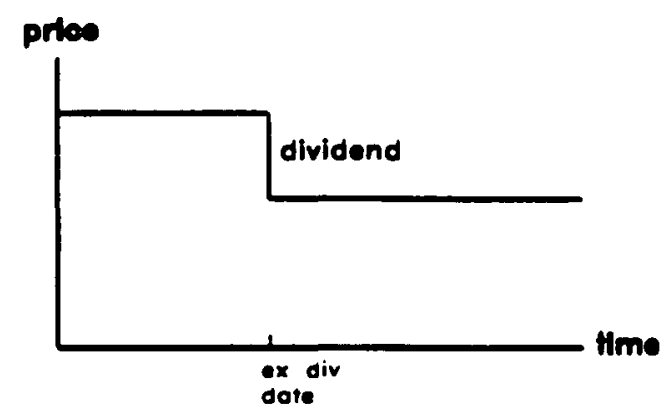

2. Including dividend receipte on pajment date

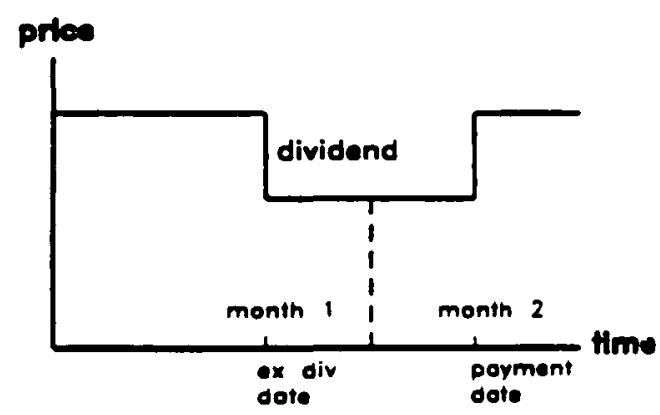

3. Including dividend receipts on the ex dividend date

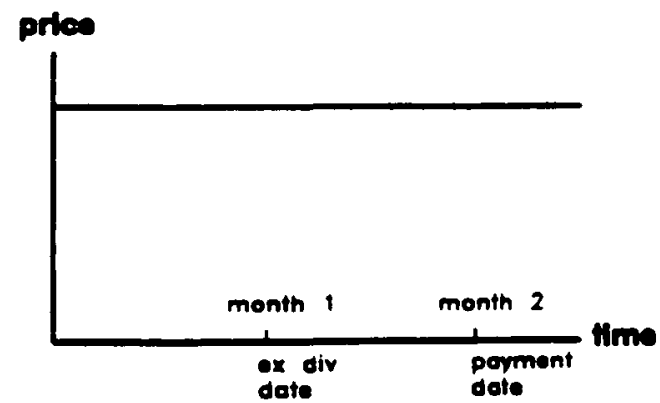

